\title{
Bone development in suckled pigs
}

\author{
By R. BLAIR*, J. R. B. DIACK AND R. M. MACPHERSON \\ Rowett Research Institute, Bucksburn, Aberdeen
}

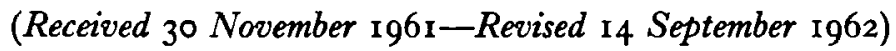

This report is the second of a series describing experiments with the overall aim of determining the requirements of the young pig for calcium and phosphorus (see Blair, 1963).

The primary aim of this second study was to provide radiological information on the pattern of development of the limb bones of pigs up to 8 weeks of age. It was hoped that this information could be used later in assessing the adequacy of the $\mathrm{Ca}$ and $P$ content of a synthetic diet.

The weaning of pigs from the sow at an early age normally results in a check in liveweight gain (Smith \& Lucas, 1956-7) which is probably reflected in a check in the growth of the skeleton, and therefore a suckled litter was chosen for this study. Samples of the sow's milk were withdrawn regularly for analysis to determine whether, by comparison with previously obtained data on the composition of milk from the Wessex Saddleback breed (Lodge, 1958), the nutrition of the piglets could be regarded as normal. In addition chemical analyses were made on the whole skeletons of the pigs at 8 weeks together with radiographic density measurements of selected bones.

\section{EXPERIMENTAL}

Animals. A Wessex Saddleback sow, known to produce good litters, was mated to a Landrace boar. She was put into a farrowing pen a few days before full term and eight piglets were born. They were weighed soon after birth and given identification marks. One weak piglet died on the 8th day.

To prevent iron-deficiency anaemia the piglets were dosed orally with a mixture of glucose and reduced iron at 3 days and at weekly intervals thereafter until supplementary food was given. At 10 days the males were castrated. Live weights were recorded weekly.

At 8 weeks of age the piglets were killed by captive-bolt pistol.

Radiographs. Radiographs were taken of the limbs at birth and immediately after each weekly weighing up to 8 weeks of age. The operative voltage was progressively raised from $62 \mathrm{kV}$ at birth to $70 \mathrm{kV}$ at 8 weeks, otherwise the radiographic ratings were kept constant at $100 \mathrm{~mA}$, exposure $0.12 \mathrm{sec}$ and tube focus-film distance $36 \mathrm{in}$. From the radiographs the following measurements were made with a Vernier microscope:

(a) medial length of the diaphysis (shaft) only of the radius and tibia;

- Present address: Department of Agriculture, University of Aberdeen. 
(b) distal breadth of the radial diaphysis and proximal breadth of the tibial diaphysis;

(c) length and breadth of the distal epiphysis of the ulna;

(d) length and breadth of the proximal epiphysis of the tibia;

(e) width of cartilage between the latero-distal edge of the ulna and the lateroproximal edge of the epiphysis of the ulna.

At the end of the experiment radiographs were also made, in the dry flesh-free state, of the mandible, cervical vertebras I, 3, 5 and 7 , thoracic vertebras I, 5, 8, I2 and 15 , lumbar vertebras 1,3 and 5, sacrum, radius, humerus and femur. Radiographic ratings were again kept constant at $100 \mathrm{~mA}$, exposure $0.1 \mathrm{sec}$, tube focusfilm distance $3^{6} \mathrm{in}$. and $66 \mathrm{kV}$ except with the cervical vertebras for which the voltage was reduced to $62 \mathrm{kV}$.

Milking technique. The sow was milked twice weekly to provide samples of milk for analysis. The method adopted was essentially that described by Lodge (1958) but differed in that the milk was withdrawn by hand. The procedure consisted in restraining the sow in a specially designed crate and then injecting $0.5 \mathrm{ml}$ oxytocin (Pitocin; Parke, Davis and Co. Ltd, containing ro i.u. oxytocin $/ \mathrm{ml}$ ) in physiological saline into an ear vein, a short time after which milk ejection took place. This volume of oxytocin was found to induce a response yielding an amount of milk equivalent to that 'obtained by the pigs at one sucking. Sometimes it was impossible to locate an ear vein owing to the thickness of surrounding tissue; on these occasions larger volumes of oxytocin were given intramuscularly.

Chemical analysis. The total solids in the milk samples were determined by drying at $100^{\circ}$ (Ling, 1948), crude protein by the macro-Kjeldahl method, lactose by McDowell's (194I) adaptation of Lane and Eynon's method, fat by the Gerber method, ash by the method described by Ling (1948), Ca by a modification of the standard oxalate method which prevented co-precipitation of $\mathrm{Mg}$ (Holth, 1949), and P by the method of Rickey \& Avens (1955).

Estimation of milk yield. Again the method adopted was the one already in use at this Institute (Lodge, 1958) which has been found to give satisfactory results, and the estimation was done twice weekly. It consisted in weighing the litter accurately before and after suckling, and the difference in weight, provided there had been no loss from urination or defaecation, was equal to the weight of milk yielded. Recording in this manner over $7 \frac{1}{2} \mathrm{~h}$ has been found to give a representative picture of yield over $24 \mathrm{~h}$. The recording procedure was as follows. Over the total period of $7 \frac{1}{\mathrm{~h}} \mathrm{~h}$ the piglets were separated from the sow and placed on a bed of chopped straw under heating lamps. A few minutes before the end of the normal suckling period, i.e. $\mathrm{I}_{4}-\mathrm{I}_{2}^{1} \mathrm{~h}$ depending on stage of lactation, the piglets were removed from under the heating lamps and placed in a large wooden crate or a corner of the pen where the majority urinated and defaecated. They were then weighed individually to the nearest $5 \mathrm{~g}$, replaced under the heating lamps until all had been weighed and then placed beside the sow. As soon as suckling was completed the piglets were removed, weighed and replaced under the lamps. The weighing procedure was repeated five times at the stated intervals and from the total weight gain at each suckling the milk yield of the 
sow over $24 \mathrm{~h}$ was calculated. Milk composition has been shown to vary between teats (Schmidt \& Lauprecht, 1926; Smith, 1952; Pond, VanVleck \& Hartman, 1962), and milk yield may likewise vary since piglets sucking anterior teats have higher intakes (Donald, x937; Barber, Braude \& Mitchell, 1955), although other work has shown no significant difference in milk output from different teats by milking (Pond et al. 1962). However, as each piglet always sucks the same teat or teats (Lodge, 1958) it was presumed that the milk consumed by each piglet in the $24 \mathrm{~h}$ was representative in quantity and composition of that received in each 3 or 4 days.

Feeding. The sow was given two feeds a day; each consisted of $6 \mathrm{lb}$ of a meal mixture the composition of which is given by Lodge (1957). This diet contained $0.75 \% \mathrm{Ca}$ and $0.69 \% \mathrm{P}$. During feeding the sow was separated from the litter to prevent the piglets from gaining access to the feed trough.

Supplementary food (Lodge, 1957) was given to the litter at the beginning of the 7 th week to allow for the rapid decline in milk yield expected at this time. In practice supplementary feeding would be introduced earlier but, since we wished to calculate the proportion of dietary $\mathrm{Ca}$ and $\mathrm{P}$ retained in the skeleton, the introduction of a meal mixture of lower digestibility than sow's milk (Freese, 1958; I. A. M. Lucas and R. M. Livingston, 1960, unpublished) was delayed as long as possible.

Supplementary food was hand-fed to the piglets to appetite in individual compartments at 10 a.m., I p.m. and 4 p.m. daily. The meal was mixed with an equal weight of water and if any food was refused the residue was weighed to give the amount eaten.

Removal of the skeleton. At 8 weeks of age the piglets were slaughtered and eviscerated. The head was separated from the body at the occipital articulation; the body was divided between the last thoracic and the first lumbar vertebras and the limbs were removed complete. Subsequently the parts of the bodies were boiled in water for $\mathrm{I} h$, the skin having been removed but sufficient flesh retained to prevent damage to the cartilage. The bones were then dissected free from the remaining flesh. It is not known whether this procedure resulted in leaching of organic matter from the bones.

After drying at room temperature for about I week the bones were dipped in a $2 \%(w / v)$ solution of thymol in acetone to prevent fungal growth.

Bone analysis. After they had been extracted in boiling acetone and dried to constant weight at $100^{\circ}$ the axial skeleton, minus the right mandible, and the bones of the left limbs were weighed and the ash was determined by incineration at $700^{\circ}$; the ash was analysed for $\mathrm{Ca}$ and $\mathrm{P}$ by the methods already described.

Skeletons obtained from three apparently normal pigs of average birth weight were also analysed to provide details of mineral composition of the skeleton at birth.

Bone density. The same bones from each piglet were arranged side by side and a radiograph was taken. A previously developed method of scoring based on the densities of the shadows and the degree of development of the cancellous trabeculae (Benzie, Boyne, Dalgarno, Duckworth \& Hill, 1959) was used.

Statistical methods. The results were analysed by the conventional techniques of analysis of variance and regression analysis. 


\section{RESULTS}

Performance of the piglets. The live weights are set out in Table I. The general health of the sow and litter was good although some piglets scoured a little; they responded to oral dosing with chlortetracycline (Aurofac $2 \mathrm{~A}$ (Cyanamid of Great Britain Ltd), containing $3.6 \mathrm{~g}$ chlortetracycline hydrochloride/lb). Rates of weight gain and weights at 8 weeks were satisfactory, except for piglet no. 6 which grew slowly from the $4^{\text {th }}$ to the $7^{\text {th }}$ week.

Table r. Live weights of the piglets $(l b)$

\begin{tabular}{|c|c|c|c|c|c|c|c|}
\hline \multirow{2}{*}{$\begin{array}{c}\text { Age } \\
\text { (weeks) }\end{array}$} & \multicolumn{7}{|c|}{ Pig no. } \\
\hline & I & 2 & 3 & 4 & 5 & 6 & 8 \\
\hline$\circ$ & $3 \cdot 7$ & $2 \cdot 5$ & $4^{\cdot 1}$ & $2 \cdot 8$ & 3.4 & $3 \cdot 2$ & $3 \cdot 2$ \\
\hline I & $7 \cdot 2$ & $5 \cdot 0$ & $5 \cdot 0$ & 47 & $5 \cdot 7$ & $6 \cdot 3$ & $7 \cdot 1$ \\
\hline 2 & $12 \cdot 7$ & $9 \cdot 4$ & $6 \cdot I$ & $7 \cdot 3$ & $9 \cdot 2$ & 10.8 & I $2 \cdot 8$ \\
\hline 3 & $17 \cdot 2$ & 14.4 & $8 \cdot 4$ & $9 \cdot 9$ & $12 \cdot 7$ & $15 \cdot 8$ & 18.6 \\
\hline 4 & $2 I \cdot 5$ & $17 \cdot 9$ & 10.8 & $12 \cdot 7$ & $15 \cdot 3$ & 19.7 & $23 \cdot 9$ \\
\hline 5 & $26 \cdot 1$ & $22 \cdot 4$ & I4.I & I5.5 & I 9.4 & $21 \cdot 0$ & $28 \cdot 6$ \\
\hline 6 & $30 \cdot 1$ & $26 \cdot 9$ & $16 \cdot 8$ & I $8 \cdot 0$ & $22 \cdot 0$ & $2 I \cdot I$ & $32 \cdot 8$ \\
\hline 7 & $38 \cdot 4$ & 34.5 & $22 \cdot 9$ & 25.0 & $28 \cdot 9$ & 24.4 & 40.5 \\
\hline 8 & $46 \cdot 3$ & $41 \cdot 5$ & $30 \cdot 0$ & $32 \cdot 5$ & $36 \cdot 2$ & $31 \cdot 2$ & $49 \cdot 9$ \\
\hline
\end{tabular}

Yield and composition of milk. Estimated daily milk yields and results of milk analyses are given in Table 2.

Yield rose from $3000 \mathrm{~g}$ daily at the beginning of lactation to a peak of over $7000 \mathrm{~g}$ by the $4^{\text {th }}$ week, and did not decline rapidly until the end of the 6th week. It was still relatively high at the end of the 8 th week.

The content of total solids in the milk fluctuated somewhat and there appeared to be a negative correlation between total solids and yield. The percentage of fat fluctuated in the same manner as the percentage of total solids.

Table 2. Yield and composition of the sow's milk

\begin{tabular}{|c|c|c|c|c|c|c|c|c|}
\hline \multirow[b]{2}{*}{ Week } & \multirow{2}{*}{$\begin{array}{l}\text { Estimated } \\
\text { daily } \\
\text { yield } \\
(\mathrm{g})\end{array}$} & \multicolumn{7}{|c|}{ Composition $(\mathrm{g} / \mathrm{I} 00 \mathrm{~g})$} \\
\hline & & $\begin{array}{l}\text { Total } \\
\text { solids }\end{array}$ & $\begin{array}{l}\text { Crude } \\
\text { protein }\end{array}$ & Lactose & Fat & Ash & Calcium & Phosphorus \\
\hline I & 3380 & $25 \cdot 2$ & $6 \cdot 3$ & $6 \cdot 6$ & $11 \cdot 7$ & 0.76 & 0.1 I & 0.18 \\
\hline 2 & $554^{\circ}$ & $25 \cdot 2$ & $6 \cdot 0$ & $5 \cdot 6$ & 13.0 & 0.84 & 0.17 & 0.27 \\
\hline 3 & 6170 & $23 \cdot 3$ & $5 \% 4$ & $5 \cdot 4$ & II.5 & 0.87 & 0.22 & 0.23 \\
\hline 4 & 7430 & $21 \cdot 6$ & $5 \cdot 6$ & $5 \cdot 6$ & $9 \cdot 5$ & 0.89 & 0.22 & 0.30 \\
\hline 5 & 6860 & $23 \cdot 3$ & $6 \cdot 1$ & $5 \cdot 2$ & $I I \cdot 2$ & 0.94 & 0.20 & 0.20 \\
\hline 6 & 7050 & 23.4 & $6 \cdot 2$ & $5 \cdot 3$ & $I I \cdot I$ & 0.99 & 0.25 & 0.24 \\
\hline 7 & 5830 & $28 \cdot 8$ & $7 \cdot 6$ & 4.5 & $15 \cdot 7$ & $I \cdot I 2$ & 0.33 & 0.32 \\
\hline 8 & 5710 & 25.4 & $7 \cdot 2$ & $5 \cdot 6$ & $11 \cdot 6$ & I.09 & 0.30 & 0.25 \\
\hline
\end{tabular}

Milk consumption. The estimated weekly milk consumption of each piglet is shown in Table 3.

Consumption of supplementary food. The amount of supplementary food eaten by each piglet is shown in Table 4. 
Bone measurements. All measurements from radiographs were corrected for distortion according to the formula devised by Files (1949). Values for the length and breadth of the distal epiphysis of the ulna and for the length and breadth of the proximal epiphysis of the tibia are given in Table 5 .

Table 3. Estimated weekly milk intakes $(\mathrm{kg})$ of the piglets

\begin{tabular}{|c|c|c|c|c|c|c|c|}
\hline \multirow[b]{2}{*}{ Week } & \multicolumn{7}{|c|}{ Pig no. } \\
\hline & I & 2 & 3 & 4 & 5 & 6 & 8 \\
\hline I & $4 \cdot 4$ & $2 \cdot 6$ & $1 \cdot 0$ & $3 \cdot 3$ & 3.9 & $3 \cdot 5$ & $4 \cdot 3$ \\
\hline 2 & $7 \cdot 1$ & 6.0 & $2 \cdot 2$ & 4.5 & $5 \cdot 3$ & 5.7 & $6 \cdot 9$ \\
\hline 3 & $8 \cdot 2$ & $7 \cdot 6$ & $2 \cdot 6$ & $4 \cdot 5$ & $5 \cdot 7$ & 6.8 & $7 \cdot 5$ \\
\hline 4 & 8.7 & 7.5 & $4 \cdot 5$ & $6 \cdot 3$ & 6.9 & $8 \cdot I$ & 10.0 \\
\hline 5 & $9 \cdot 0$ & $7 \cdot 4$ & 4.0 & $5 \cdot 5$ & $6 \cdot 2$ & $5 \cdot 8$ & $10 \cdot 1$ \\
\hline 6 & 10.4 & $9 \cdot 6$ & $3 \cdot 8$ & 5.9 & $7 \cdot 1$ & 3.5 & $9 \cdot 3$ \\
\hline 7 & $8 \cdot 2$ & 6.5 & 3.5 & $4 \cdot 4$ & $4 \cdot 8$ & 4.8 & 8.6 \\
\hline 8 & $7 \cdot 0$ & $6 \cdot 2$ & $4 \cdot 5$ & $4 \cdot 6$ & $3 \cdot 7$ & $5 \cdot 7$ & $8 \cdot 5$ \\
\hline Total & $63 \cdot 0$ & 53.4 & $26 \cdot 1$ & $39 \cdot 0$ & $43 \cdot 6$ & $43 \cdot 9$ & $65 \cdot 2$ \\
\hline
\end{tabular}

Table 4. Supplementary food (kg/week) eaten by the piglets in the last 2 weeks of the experiment

$\begin{array}{cccccccc}\text { Week } & \text { I } & 2 & 3 & 4 & 5 & 6 & 8 \\ 7 & I \cdot 3 & I \cdot 2 & I \cdot 1 & 1 \cdot 2 & 1 \cdot 3 & 0.2 & 1 \cdot 0 \\ 8 & 3 \cdot 2 & 2.7 & 2.8 & 3 \cdot 0 & 3 \cdot 2 & 1 \cdot 4 & 3 \cdot 0 \\ \text { Total } & 4 \cdot 5 & 3.9 & 3.9 & 4.2 & 4 \cdot 5 & 1.6 & 4 \cdot 0\end{array}$

Table 5. Mean values $(\mathrm{cm})$ with standard deviations for length and breadth of the distal epiphysis of the ulna and of the proximal epiphysis of the tibia of the seven piglets

$\begin{array}{ccccc}\begin{array}{c}\text { Age } \\ \text { (weeks) }\end{array} & \overbrace{\text { Length }}^{\text {Distal epiphysis of ulna }} & \text { Breadth } & \overbrace{\text { Length }}^{\text {Proximal epiphysis of tibia }} \\ 0 & 0.33 \pm 0.05 & 0.23 \pm 0.06 & 0.43 \pm 0.08 & \text { Breadth } \\ 1 & 0.47 \pm 0.04 & 0.37 \pm 0.05 & 0.55 \pm 0.06 & 0.93 \pm 0.13 \\ 2 & 0.65 \pm 0.09 & 0.52 \pm 0.07 & 0.72 \pm 0.07 & 1.20 \pm 0.12 \\ 3 & 0.79 \pm 0.12 & 0.64 \pm 0.09 & 0.85 \pm 0.08 & 1.59 \pm 0.14 \\ 4 & 0.94 \pm 0.11 & 0.74 \pm 0.10 & 0.97 \pm 0.06 & 2.88 \pm 0.18 \\ 5 & 1.07 \pm 0.14 & 0.83 \pm 0.11 & 1.05 \pm 0.07 & 2.37 \pm 0.17 \\ 6 & 1.17 \pm 0.12 & 0.91 \pm 0.10 & 1.13 \pm 0.11 & 2.61 \pm 0.26 \\ 7 & 1.32 \pm 0.09 & 1.02 \pm 0.09 & 1.19 \pm 0.07 & 2.81 \pm 0.27 \\ 8 & 1.45 \pm 0.09 & 1.10 \pm 0.09 & 1.27 \pm 0.08 & 3.05 \pm 0.15\end{array}$

A relationship was found between these measurements and live weight, which could be expressed in the form of the regression equations given below. Two of these relationships are also shown in Figs. $I$ and 2 in the form of regression lines.

$$
\begin{aligned}
& y_{1}=-0.16 x+0.57 x^{2}+0.25, \\
& y_{2}=0.12 x+0.33^{2}+0.08, \\
& y_{3}=0.42 x+0.19 x^{2}+0.15, \\
& y_{4}=0.11 x+0.94 x^{2}+0.61,
\end{aligned}
$$


where $x=\log$ live weight $(\mathrm{lb}), y_{1}=$ length of ulnar epiphysis $(\mathrm{cm}), y_{2}=$ breadth of ulnar epiphysis $(\mathrm{cm}), y_{3}=$ length of tibial epiphysis $(\mathrm{cm}), y_{4}=$ breadth of tibial epiphysis (cm).

Piglet no. 6 after the age of 4 weeks proved to be an exception, the check in weight gain at this time being reflected in a skewing of the normal regression lines.

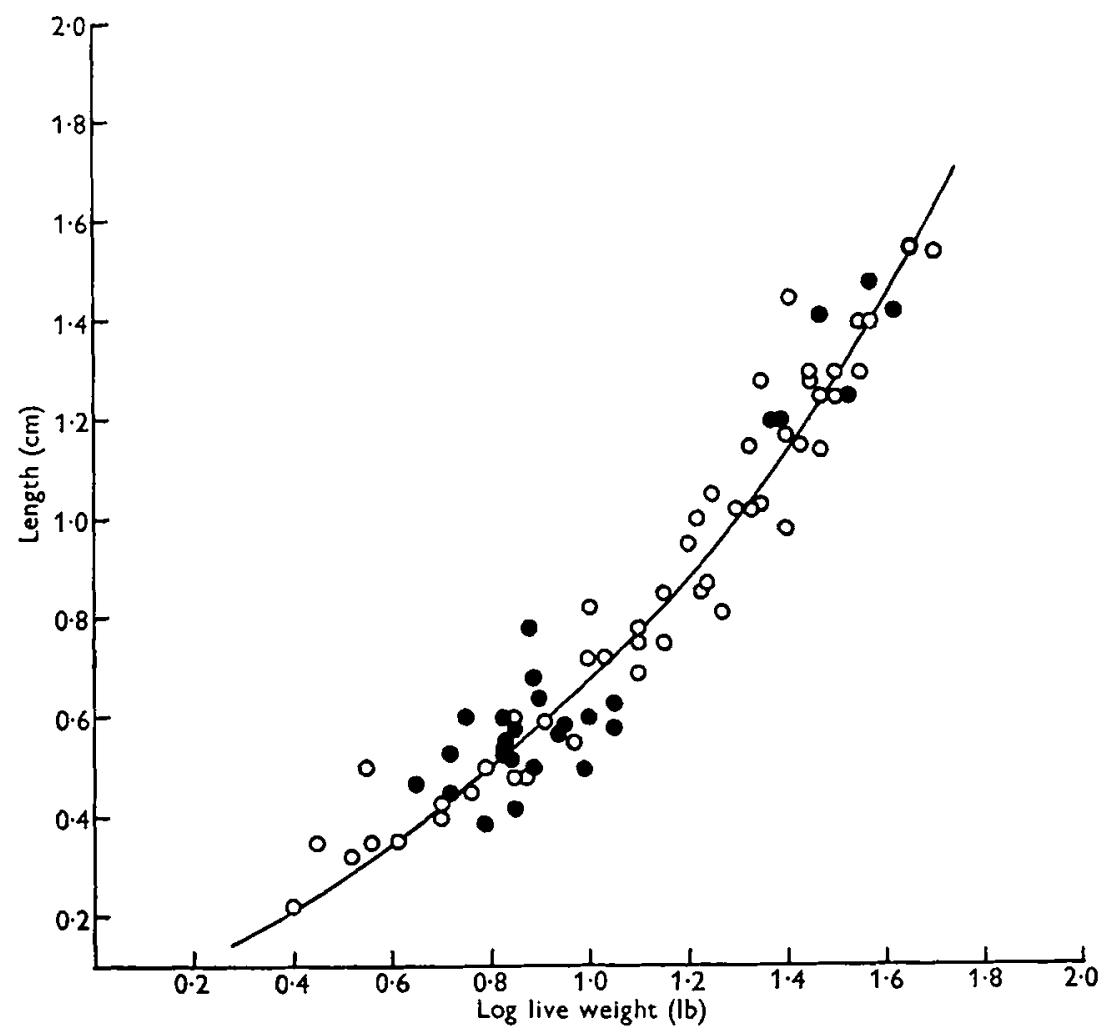

Fig. I. Regression of length of distal epiphysis of ulna of the piglets on log live weight. $O$, experimental piglets; $O$, non-experimental, unrelated piglets. Regression equation: $y=-0.16 x+0.57 x^{2}+0.25$.

Values for the width of the distal epiphysial cartilage of the ulna are given in Table 6. All the piglets showed a steady decrease in the width of this cartilage which eventually disappears at maturity when bony union of epiphysis and diaphysis takes place.

Values for the length and breadth of the diaphyses have not been included since no precise relationship was found between them and live weight.

Bone analysis. The composition of the dry fat-free bones of the skeleton in terms of ash, $\mathrm{Ca}$ and $\mathrm{P}$ is presented in Table 7 . There were consistent differences between bones in percentage ash $(P<0.001)$ but not between pigs. Ash values ranged from $62.5 \%$ for the mandible to $51 \cdot 2 \%$ for the sacrum. The ribs also had a somewhat high ash content but none of the differences among the other bones were significant. 
There were significant differences from animal to animal in the percentages in the ash of $\mathrm{Ca}(P<0.00 \mathrm{I})$ and $\mathrm{P}(P<0.00 \mathrm{I})$, and between different bones in the percentage of $\mathrm{Ca}$ in the ash $(P<0.001)$ but not in the percentage of $\mathrm{P}$.

Tables 8 and 9 show that on average $77 \%$ of the $\mathrm{Ca}$ and $42 \%$ of the $\mathrm{P}$ in the food consumed between birth and 8 weeks of age had been retained in the skeleton.

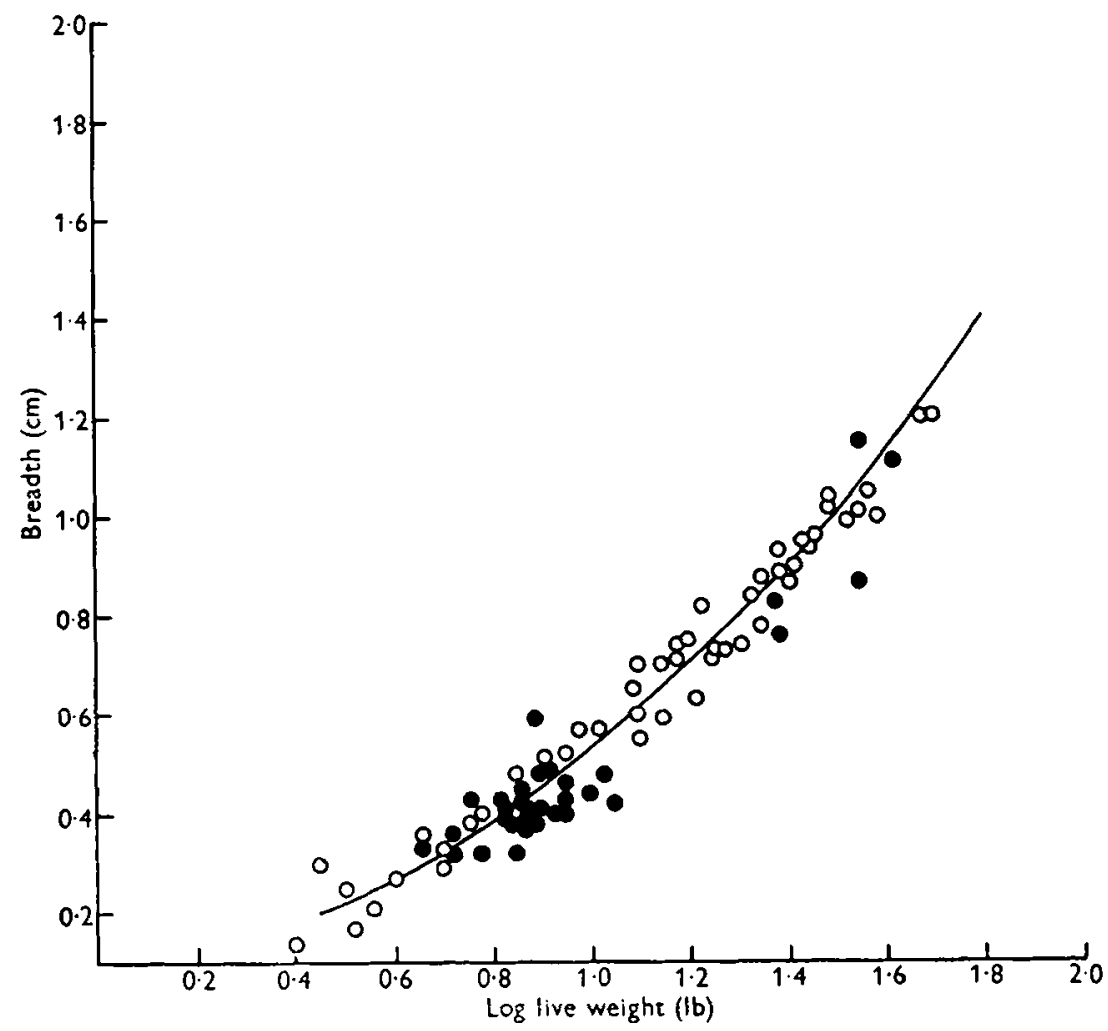

Fig. 2. Regression of breadth of distal epiphysis of ulna of the piglets on log live weight. $O$, experimental piglets; $O$, non-experimental, unrelated piglets. Regression equation: $y=0.12 x+0.33 x^{2}+0.08$.

Table 6. Mean values (cm) with standard deviations for width of distal epiphysial cartilage of the ulna of the seven piglets

$\begin{array}{cc}\begin{array}{c}\text { Age } \\ \text { (weeks) }\end{array} & \text { Width } \\ 0 & 0.33 \pm 0.02 \\ \text { I } & 0.30 \pm 0.02 \\ 2 & 0.28 \pm 0.02 \\ 3 & 0.25 \pm 0.02 \\ 4 & 0.24 \pm 0.02 \\ 5 & 0.21 \pm 0.01 \\ 6 & 0.20 \pm 0.02 \\ 7 & 0.18 \pm 0.02 \\ 8 & 0.17 \pm 0.02\end{array}$


Bone density. Values for radiographic bone density are given in Table ıo. Density was highest in the mandible ( 14.6 units) and lowest in the cervical vertebras ( 10.7 units). There were significant differences in density between pigs and between bones, but density was consistently greater in the heavier animals.

Table 7. Mean values $(\mathrm{g} / \mathrm{1} / \mathrm{g} \mathrm{g})$ with standard deviations for ash content and ash composition of the dry fat-free skeletons of the seven piglets

\begin{tabular}{|c|c|c|c|}
\hline \multirow[b]{2}{*}{ Part of skeleton } & \multirow{2}{*}{$\begin{array}{c}\text { Ash } \\
\text { content }\end{array}$} & \multicolumn{2}{|c|}{ Ash composition } \\
\hline & & Calcium & Phosphorus \\
\hline Mandible & $62 \cdot 5 \pm 0.38$ & $36.8 \pm 0.13$ & $19.3 \pm 0.87$ \\
\hline $\begin{array}{l}\text { Vertebras } \\
\text { Cervical I, 3, 5, } 7 \\
\text { Thoracic } 1,5,8,12,15 \\
\text { Lumbar I, } 3,5\end{array}$ & $\begin{array}{l}53.8 \pm 0.56 \\
54.1 \pm 0.54 \\
54.9 \pm 0.65\end{array}$ & $\begin{array}{l}39 \cdot 1 \pm 0.36 \\
38 \cdot 8 \pm 0.4 x \\
38 \cdot 4 \pm 0.22\end{array}$ & $\begin{array}{l}19.2 \pm 0.76 \\
19.5 \pm 0.67 \\
19.7 \pm 0.74\end{array}$ \\
\hline $\begin{array}{l}\text { Ribs } 1,2,13,14 \\
\text { Remainder }\end{array}$ & $\left.\begin{array}{l}56 \cdot 6 \pm 0.85 \\
56 \cdot 3 \pm 0.27\end{array}\right\}$ & $39.9 \pm 0.25$ & $19.6 \pm 0.68$ \\
\hline Sacrum & $5 x \cdot 2 \pm 0.43$ & $39.2 \pm 0.30$ & $19.3 \pm 0.68$ \\
\hline $\begin{array}{l}\text { Fore-limb } \\
\text { Radius } \\
\text { Humerus } \\
\text { Total }\end{array}$ & $\begin{array}{l}54.1 \pm 0.51 \\
53.7 \pm 0.92 \\
54.5 \pm 0.19\end{array}$ & $\begin{array}{l}39 \cdot 7 \pm 0.26 \\
38.4 \pm 0.19\end{array}$ & $\begin{array}{l}r 9.4 \pm 0.66 \\
\times 9.2 \pm 0.99\end{array}$ \\
\hline $\begin{array}{c}\text { Hind-limb } \\
\text { Femur } \\
\text { Total }\end{array}$ & $\begin{array}{l}54 \cdot 2 \pm 0.49 \\
53 \cdot 6 \pm 0.32\end{array}$ & $3^{8 \cdot 2} \pm 0.21$ & $19.4 \pm 0.90$ \\
\hline Kemainder & $55 \cdot 4 \pm 0.49$ & $37.9 \pm 0.07$ & $19 \cdot 0 \pm 0.41$ \\
\hline
\end{tabular}

Table 8. Retention of $\mathrm{Ca}$ in the skeletons of the seven piglets

\begin{tabular}{|c|c|c|c|c|c|}
\hline $\begin{array}{l}\text { Pig } \\
\text { no. }\end{array}$ & $\begin{array}{l}\text { Estimated Ca } \\
\text { in the } \\
\text { skeleton } \\
\text { at birth } \\
\text { (g) }\end{array}$ & $\begin{array}{c}\text { Total } \mathrm{Ca} \text { in } \\
\text { skeleton at } \\
8 \text { weeks } \\
\text { (g) }\end{array}$ & $\begin{array}{l}\text { Total Ca } \\
\text { laid down in } \\
\text { skeleton from } \\
\text { birth } \\
\text { (g) }\end{array}$ & $\begin{array}{c}\text { Estimated } \\
\text { Ca intake } \\
\text { from birth } \\
\text { (g) }\end{array}$ & $\begin{array}{l}\text { Ca retained } \\
\text { in skeleton } \\
\text { as percentage } \\
\text { of intake }\end{array}$ \\
\hline I & 16.8 & 198.2 & $181^{\circ} 4$ & 217.9 & $83 \cdot 2$ \\
\hline 2 & $16 \cdot 8$ & $159^{\circ} \mathrm{I}$ & $142 \cdot 3$ & 187.0 & $76 \cdot I$ \\
\hline 3 & $16 \cdot 8$ & $109^{\prime} 1$ & $92 \cdot 3$ & $126 \cdot 3$ & $73 \cdot I$ \\
\hline 4 & 16.8 & $125^{\circ}$ & 108.2 & $156 \%$ & 69.4 \\
\hline 5 & 16.8 & $130^{\circ} 1$ & 113.3 & $169^{\circ} 0$ & 67.0 \\
\hline 6 & 16.8 & 123.7 & 106.9 & 123.7 & 86.4 \\
\hline 8 & 16.8 & 1944 & $177 \cdot 6$ & $216 \cdot 2$ & $8 \mathbf{2} \cdot 1$ \\
\hline
\end{tabular}

Table 9. Retention of $P$ in the skeletons of the seven piglets

\begin{tabular}{|c|c|c|c|c|c|}
\hline $\begin{array}{l}\text { Pig } \\
\text { no. }\end{array}$ & $\begin{array}{l}\text { Estimated P } \\
\text { in the skeleton } \\
\text { at birth } \\
\text { (g) }\end{array}$ & $\begin{array}{l}\text { Total } \mathrm{P} \text { in } \\
\text { the skeleton } \\
\text { at } 8 \text { weeks } \\
(\mathrm{g})\end{array}$ & $\begin{array}{l}\text { Total P laid } \\
\text { down in skeleton } \\
\text { from birth } \\
(\mathrm{g})\end{array}$ & $\begin{array}{l}\text { Estimated } \\
P \text { intake } \\
\text { from birth } \\
\quad(g)\end{array}$ & $\begin{array}{c}P \text { retained } \\
\text { in skeleton as } \\
\text { percentage of } \\
\text { intake }\end{array}$ \\
\hline I & $7 \cdot 8$ & $94 \cdot x$ & $86 \cdot 3$ & 200.8 & $43 \cdot 0$ \\
\hline 2 & $7 \cdot 8$ & $77 \cdot 9$ & $69 \cdot 2$ & 170.3 & $40 \cdot 6$ \\
\hline 3 & $7 \cdot 8$ & 56.4 & $48 \cdot 6$ & 103.7 & $46 \cdot 9$ \\
\hline 4 & $7 \cdot 8$ & $64 \cdot 2$ & $5^{6 \cdot 4}$ & 136.9 & $4 I \cdot 2$ \\
\hline 5 & $7 \cdot 8$ & $66 \cdot 0$ & $58 \cdot 2$ & 150.3 & $38 \cdot 7$ \\
\hline 6 & $7 \cdot 8$ & 62.5 & 54.7 & 126.5 & $43 \cdot 2$ \\
\hline 8 & $7 \cdot 8$ & 96.4 & $88 \cdot 6$ & $202 \cdot 5$ & $43 \cdot 8$ \\
\hline
\end{tabular}


Table 10. Mean values with standard deviations for radiographic density (units*) of flesh-free bones of the seven piglets

\begin{tabular}{|c|c|}
\hline Part of skeleton & Density \\
\hline Mandible & $14 \cdot 6 \pm 0.74$ \\
\hline $\begin{array}{l}\text { Vertebras } \\
\text { Cervical 1, 3,5,7 } \\
\text { Thoracic } 1,5,8,12 \text {, } 5 \\
\text { Lumbar } 1,3,5\end{array}$ & $\begin{array}{l}10.7 \pm 0.84 \\
10.9 \pm 0.67 \\
10.8 \pm 0.73\end{array}$ \\
\hline Sacrum & $10.8 \pm 0.62$ \\
\hline $\begin{array}{l}\text { Fore-limb } \\
\text { Radius } \\
\text { Humerus }\end{array}$ & $\begin{array}{l}13.8 \pm 0.81 \\
13.8 \pm 0.82\end{array}$ \\
\hline - Benzie et al. (1959). & $13.5 \pm 0.89$ \\
\hline
\end{tabular}

\section{DISCUSSION}

Young piglets grow very rapidly, and consequently the X-ray beam has to be steadily increased in intensity to penetrate the greater thickness of tissue and yet give proper definition of bone structure. Therefore, because the radiographic ratings were not kept constant but were adjusted according to age, it was not possible to measure the comparative density of the limb bones while the pigs were still alive. Thus no attempt could be made to relate bone density to age or live weight and, instead, quantitative measures of bone growth were sought.

The first procedure was to measure the length and breadth of the long bones and attempt to correlate these measurements with age or live weight. It was obvious that there was a positive correlation between size of the long bones and live weight but it was not very precise. However, a more precise relationship was found between the length and breadth of two of the epiphyses of the long bones and live weight. The curves obtained for individual piglets differed very slightly, but the relationship would appear to be a close one when the limitations of the experiment are considered. The measurements taken from the radiographs were corrected for distortion of the image caused by magnification but, as the position of the limb at the instant of exposure may not always have been horizontal, further distortion that could not be corrected may have occurred.

Again, a single weighing per week over a period when rapid development is taking place is, perhaps, not a very good measure of true body-weight.

Since the values used in establishing the relationship were derived from closely related animals, similar measurements were obtained for six piglets of weight range $23.9-43 \cdot \circ \mathrm{lb}$ and for a large number of piglets at 10 days of age. Some of these pigs were pure-bred and others were crosses. The values obtained for these animals fitted the established regressions closely (Figs. I and 2), suggesting that the relationship between the size of the epiphyses and live weight may be true of young pigs in general, although confirmation is clearly required. 
Measurements were also made of the width of the distal epiphysial cartilage of the ulna, and a steady decrease in width was apparent in all the piglets. In common with the epiphyses referred to, this cartilage is particularly useful for study since it is well defined and shows a reasonable change in size over 8 weeks.

Throughout the experiment it was obvious that the milk of the sow had a nutritive value higher than the average for the Wessex breed (Lodge, 1958), owing largely to the very high fat content, which at one stage was almost $16 \%$, and also to a slightly higher content of lactose and crude protein. The total yield was, however, lower than the average for this breed (Lodge, 1958), perhaps because of the small litter, and as a result the yield of total solids did not differ markedly from the normal. The $P$ content was also higher than has been previously reported for the Large White and Berkshire breeds respectively (Braude, Coates, Henry, Kon, Rowland, Thompson \& Walker, 1947; Perrin, 1955), perhaps because there was some $P$ in the form of a phospholipid associated with fat, since the $\mathrm{Ca}$ content was no greater than normal (Braude et al. 1947; Perrin, 1955). This high P content may have influenced bone growth to some extent, but no evidence of such influence was found in the relationships between epiphysial size and live weight. In addition, the $\mathrm{Ca}: \mathrm{P}$ ratio of the milk remained within the accepted range of values beyond which bone deformities usually result (Shohl, 1939).

Retention of $\mathrm{Ca}$ in the skeleton was high in view of the extent of breakdown and remodelling of bone tissue that must have taken place during the 8 weeks of life. Retention of $\mathrm{P}$ was lower, being about half that of $\mathrm{Ca}$, which is consistent with the requirement of bone for $\mathrm{Ca}$ and $\mathrm{P}$ in the ratio of $2: \mathrm{r}$. The total amount of $\mathrm{P}$ retained, however, would be higher than that laid down in the skeleton since $\mathrm{P}$ is also required for soft-tissue development.

At 8 weeks of age the heavier pigs, as expected, had bigger skeletons, and bone density measurements showed that the bones were better mineralized. The concentration of ash and $\mathrm{Ca}$ in ash in the skeletons support the latter findings, but results for $\mathrm{P}$ do not. Since bone size per se is not necessarily correlated with mineral content (Maynard \& Loosli, I956) it was concluded that the total amount of $\mathrm{Ca}$ and $\mathrm{P}$ ingested was probably the essential factor determining the degree of bone mineralization. The pigs receiving more $\mathrm{Ca}$ and $\mathrm{P}$ had higher total food intakes, which resulted in faster live-weight gain and increased skeletal growth. In only one pig was density not associated with live weight at 8 weeks, namely, pig no. 6, whose bones showed lines of arrested growth. These were presumably caused by the check in live-weight gain between the $4^{\text {th }}$ and $7^{\text {th }}$ weeks.

\section{SUMMARY}

I. Bone development was studied radiologically in a litter of seven suckled pigs over the first 8 weeks of life.

The sow was milked regularly to provide samples of milk for analysis, and the daily milk yield of the sow and the milk intake of each pig were determined twice weekly by weighing the piglets before and after sucking. Supplementary food was given individually to the piglets for the last 2 weeks, after which they were slaughtered. 
2. Growth performance of the litter was good except for one pig. The mean weight at 8 weeks was $38 \mathrm{lb}$.

3. The sizes of the distal epiphysis of the ulna and proximal epiphysis of the tibia were significantly correlated with live weight. The distal epiphysial cartilage of the ulna showed a steady decrease in width over the 8-week period.

4. Chemical analyses of individual bones and groups of bones provided values for the ash, calcium and phosphorus contents of the skeleton at 8 weeks and enabled the retention of ingested $\mathrm{Ca}$ and $\mathbf{P}$ to be calculated.

5. Bone density measurements indicated that at 8 weeks the heavier pigs, as expected, had bones of higher radiographic density.

We are indebted to the following members of staff of the Rowett Research Institute: Professor I. A. M. Lucas for advice and help in the preparation of this paper; $\mathrm{Mr} \mathrm{D}$. Benzie for advice on radiology; Mr A. W. Boyne and Mr I. McDonald for statistical analysis of the results and Mrs S. J. MacPherson for technical assistance.

\section{REFERENCES}

Barber, R. S., Braude, R. \& Mitchell, K. G. (I955). J. agric. Sci. 46, 97.

Benzie, D., Boyne, A. W., Dalgarno, A. C., Duckworth, J. \& Hill, R. (1959). F. agric. Sci. 52, I.

Blair, R. (1963). Brit. F. Nutr. 17, r.

Braude, R., Coates, M. E., Henry, K. M., Kon, S. K., Rowland, S. J., Thompson, S. Y. \& Walker, D. M. (1947). Brit. F. Nutr. I, 64.

Donald, H. P. (1937). Emp. F. exp. Agric. 5, 361 .

Files, G. W. (editor) (1949). Medical Radiographic Technic. Springfield, Ill.: C. C. Thomas.

Freese, H. H. (1958). Arch. Tierernähr. 8, 330.

Holth, T. (1949). Analyt. Chem. 21, 1221.

Ling, E. R. (1948). Textbook of Dairy Chemistry. Vol. 2. London: Chapman and Hall.

Lodge, G. A. (1957). F. agric. Sci. 49, 200.

Lodge, G. A. (1958). The energy requirements of lactating sows and the influence of total food consumption during lactation upon milk production. Ph.D. Thesis, University of Aberdeen.

McDowell, A. K. R. (r941). Э. Dairy Res. 12, 131.

Maynard, L. A. \& Loosli, J. K. (1956). Animal Nutrition, $4^{\text {th }}$ ed. New York: McGraw-Hill Book Co. Inc.

Perrin, D. R. (1955). F. Dairy Res. 22, 103.

Pond, W. G., VanVleck, L. D. \& Hartman, D. A. (1962). F. Anim. Sci. 21, 293.

Rickey, G. F. \& Avens, A. W. (1955). F. Ass. off. agric. Chem. Wash. 38, 898.

Schmidt, J. \& Lauprecht, E. (1926). Züchtungskunde, 1, 50.

Shohl, A. T. (1939). Mineral Metabolism. New York: Reinhold Publishing Corp.

Smith, D. M. (1952). Proc. N.Z. Soc. Anim. Prod. 12, 102.

Smith, H. \& Lucas, I. A. M. (1956-7). F. agric. Sci. 48, 220. 